Ahmedin Lekpek

Državni univerzitet

u Novom Pazaru

alekpek@np.ac.rs
UPRAVLJANJE KREDITNIM

RIZIKOM U

ISLAMSKOM

BANKARSTVU

\title{
Rezime
}

Tokom viševekovne prakse konvencionalnog bankarstva, razvijene su brojne tehnike i instrumenti za ublažavanje kreditnog rizika i proces njihove evolucije, zbog stalnih promena $\mathrm{u}$ bankarskom poslovanju, i dalje traje. Islamske banke, pak, još uvek nisu uspele da razviju autentične, šerijatski prihvatljive tehnike za upravljanje kreditnim rizikom u obimu dovoljnom da zadovolji njihove potrebe. Stoga, one su često primorane da koriste konvencionalne tehnike, čija je dosledna primena u islamskom bankarstvu, usled šerijatske neusklađenosti pojedinih tehnika ili načina na koji se one u konvencionalnom bankarstvu implementiraju, dosta ograničena. U ovom radu, analiziraćemo konvencionalne tehnike upravljanja i ublažavanja kreditnog rizika i njihovu primenjivost $\mathrm{u}$ islamskom bankarstvu, praksu upravljanja kreditnim rizikom u islamskim bankama, ostvarene rezultate i faktore koji utiču na pojavu i intenzitet kreditnog rizika u islamskom bankarstvu.

Ključne reči: islam, bankarstvo, kreditni rizik, Bazelski standardi, neperformansni zajmovi, faktori kreditnog rizika

JEL: G21, G32 


\section{CREDIT RISK MANAGEMENT IN ISLAMIC BANKING}

Ahmedin Lekpek

State University of Novi Pazar alekpek@np.ac.rs

\section{Summary}

During the centuries of conventional banking practice, a number of credit risk mitigation techniques and instruments have been developed and the process of their evolution, due to constant changes in the banking business, is continuing. Islamic banks, however, have not yet managed to develop authentic, Shariah acceptable credit risk management techniques to the extent sufficient to meet their needs. Therefore, they are often forced to use conventional techniques, whose consistent application in Islamic banking, due to the Shariah non-compliance of certain techniques or the way in which they are implemented in conventional banking, is quite limited. In this paper, we will analyze the conventional credit risk management and mitigation techniques and their applicability in Islamic banking, the credit risk management practices in Islamic banks, the achieved results and factors that influence the emergence and intensity of credit risk in Islamic banking.

Keywords: Islam, banking, credit risk, Basel standards, non-performing loans, credit risk factors

JEL: G21, G32 


\section{Uvod}

Kreditni rizik je opasnost da druga ugovorna strana neće ispuniti svoje obaveze u skladu sa dogovorenim uslovima (Basel Committee on Banking Supervision - BCBS, 2000, str. 1). Smatra se najznačajnijim rizikom u bankarskom poslovanju i ključnim uzrokom stečajeva banaka, a to nisu promenile ni brojne finansijske inovacije koje su pojavile u poslednjih nekoliko decenija (Van Greuning i Brajović Bratanović, 2006, str. 135). Istorija upravljanja kreditnim rizikom je veoma duga i seže sve do starog veka i prvih velikih civilizacija. Već u tom periodu su nastali prvi instrumenti ublažavanja dejstva kreditnog rizika, koji su se aktivno koristili. U Asiriji i Vavilonu, kolateral je bio nezaobilazni element kreditnih ugovora, dok je u antičkoj Grčkoj, pored postojanja rudimentarnih oblika kredita obezbeđenih hipotekom, bila zastupljena i garancija uglednih građana kao sredstvo obezbeđenja (Homer \& Sylla, 2005, str. 28, 35, 37). Korišćenje kolaterala nije bilo strano ni prvim muslimanima, o čemu svedoči podatak da je i sam Muhamed s.a.v.s. kolateralom, koji je $\mathrm{u}$ terminologiji islamskog bankarstva poznat kao al-rahn, garantovao vraćanje svojih dugova (Azmi, Nur, Hussin \& Basiruddin, 2015, str. 455).

Dinamičniji razvoj tehnika upravljanja kreditnim rizikom i pojava sofisticiranih hedžing instrumenata, desili su se znatno kasnije. Prvi ozbiljniji oblici robnih derivata pojavili su se u Japanu početkom 18. veka, institucionalizovana tržišta na kojima se njima aktivno trgovalo, polovinom 19. veka u SAD, dok je trgovina finansijskim derivatima, kao najsavremenijim instrumentima za ublažavanje dejstva rizika, započeta u SAD tek 70-tih godina 20. veka (Dionne, 2013, str. 151). Ipak, sve su to bila rešenja primerena upravljanju kreditnim rizikom na nivou pojedinačnih finansijskih institucija. Tek je usvajanjem Bazelskih dokumenata (BCBS, 1988, 2004) stvorena osnova za harmonizaciju propisa i seta preporučenih tehnika upravljanja kreditnim rizikom, definisanje standarda i efikasniju regulaciju procesa upravljanja kreditnim rizikom u bankama.

Šerijatska zabrana kamate je onemogućila islamskim bankama angažovanje $u$ konvencionalnim kreditnim poslovima, pa su stoga islamske banke svoje poslovanje zasnovale na brojnim, šerijatski prihvatljivim poslovima. Da bi se na adekvatan način shvatilo dejstvo kreditnog rizika u islamskom bankarskom poslovanju, neophodno je prethodno navedenu definiciju kreditnog rizika delimično dopuniti i modifikovati za svaku vrstu islamskih finansijskih aranžmana. U islamskom bankarstvu, kreditni rizik se može definisati kao mogućnost da (Akkizidis \& Khandelwal, 2008, str. 119-120): kupac neće moći da isplaćuje dogovorene rate (murabeha); zakupac neće moći da plaća dogovorene rente ili se ranije povuče iz posla (idžara); prodavac neće isporučiti robu na vreme ili kupac neće platiti dogovorenu cenu (selem), proizvođač ili izvođač radova neće isporučiti traženu aktivu u dogovoreno vreme ili kupac neće platiti dogovorenu cenu (istisna'); finansirani projekat neće doneti očekivani profit (mudareba i mušareka).

Bazelski dokumenti nisu prepoznali specifičnost i potrebe islamskih banaka, pa su stoga međunarodne islamske regulatorne institucije definisale standarde upravljanja rizicima i kapitalom koji su usklađeni sa principima islamskog bankarstva. Konkretno, Odbor za islamske finansijske usluge (Islamic Financial Services Board - IFSB) i Računovodstvena i revizorska organizacija za islamske finansijske institucije (Accounting and Auditing Organization for Islamic Financial Institutions - AAOIFI), kreirali su standarde upravljanja kapitalom $\mathrm{u}$ islamskim bankama (AAOIFI, 1999; IFSB, 2005a), dok je IFSB dao i preporuke za efikasno upravljanje rizicima $\mathrm{u}$ islamskom bankarstvu (IFSB, 2005b). Proces upravljanja kreditnim rizikom $\mathrm{u}$ islamskim bankama je složen i zahtevan. Njegov detaljniji prikaz biće dat u nastavku, kroz analizu prihvatljivosti konvencionalnih tehnika upravljanja kreditnim rizikom, prakse upravljanja rizikom $\mathrm{u}$ islamskim bankama, nivoa njihove izloženosti pojedinim privrednim sektorima i geografskim područjima, zastupljenosti neperformansnih plasmana $\mathrm{u}$ aktivi islamskih banaka, kao i faktora koji utiču na intenzitet dejstva kreditnog rizika u islamskom bankarskom poslovanju. 


\section{Introduction}

Credit risk is the risk that the other contracting party will not fulfill its obligations in accordance with the agreed terms (Basel Committee on Banking Supervision - BCBS, 2000, p. 1). It is considered the most significant risk in banking operations and the key cause of bank bankruptcies, which has hardly changed after a number of financial innovations that have emerged in the last few decades (Van Greuning \& Brajović Bratanović, 2006, p. 135). The history of credit risk management is very long and goes back to the ancient times and the first major civilizations. In that period, the first instruments for the mitigation of credit risk effects were already actively used. In Assyria and Babylon, collateral was an indispensable element of credit agreements, while in Ancient Greece, in addition to the existence of rudimentary forms of loans secured by mortgages, a guarantee of respectable citizens as a means of security was also present (Homer \& Sylla, 2005, p. 28, 35, 37). The use of collateral was not foreign to the first Muslims either, as evidenced by the fact that Muhammad s.a.v.s. used collateral, which is, in the terminology of Islamic banking, known as al-rahn, to guarantee the repayment of his debts (Azmi, Nur, Hussin \& Basiruddin, 2015, p. 455).

The more dynamic development of credit risk management techniques and the emergence of sophisticated hedging instruments occurred much later. The first more serious forms of commodity derivatives emerged in Japan in the early 18th century, the institutionalized markets on which they were actively traded in the mid-19th century in the United States, while trading in financial derivatives, as the most modern instruments for mitigating risk, did not start until the 1970s in the United States (Dionne, 2013, p. 151). Nevertheless, all those were the solutions suitable for managing credit risk at the level of individual financial institutions. It was the adoption of the Basel Documents (BCBS, 1988, 2004) that created the basis for the harmonization of regulations and a set of recommended credit risk management techniques, definition of standards and a more efficient regulation of the credit risk management process in banks.

The Shariah ban on interest prevented
Islamic banks from engaging in conventional lending, hence Islamic banks based their operations on numerous, Shariah acceptable businesses. In order to adequately understand the effect of credit risk in Islamic banking, it is necessary to partially supplement and modify the aforementioned definition of credit risk for each type of Islamic financial arrangements. In Islamic banking, credit risk can be defined as a possibility that: the buyer will not be able to pay the agreed installments (murabahah); the lessee will not be able to pay the agreed annuity or will withdraw from the business earlier (ijarah); the seller will not deliver the goods in time or the buyer will not pay the agreed price (salam), the manufacturer or contractor will not deliver the requested assets at the agreed time or the buyer will not pay the agreed price (istisna'); the financed project will not bring the expected profit (mudarabah and musharakah) (Akkizidis \& Khandelwal, 2008, p. 119-120).

The Basel documents have not recognized the specificity and needs of Islamic banks, and hence the international Islamic regulatory institutions have defined the risk and capital management standards that are in line with the principles of Islamic banking. In particular, the Islamic Financial Services Board (IFSB) and the Accounting and Auditing Organization for Islamic Financial Institutions (AAOIFI) have created the capital management standards in Islamic banks (AAOIFI, 1999; IFSB, 2005a), while the IFSB has also given recommendations for effective risk management in Islamic banking (IFSB, 2005b). The credit risk management process in Islamic banks is complex and demanding. A more detailed elaboration on it is given below, through the analysis of the acceptability of conventional credit risk management techniques, risk management practices in Islamic banks, the level of their exposure to particular economic sectors and geographical areas, the share of non-performing loans in the assets of Islamic banks, as well as the factors that influence the intensity of the credit risk effect in Islamic banking. 


\section{Primenjivost konvencionalnih tehnika upravljanja kreditnim rizikom $\mathbf{u}$ islamskom bankarstvu}

Tokom viševekovne prakse konvencionalnog bankarstva, razvijene su brojne tehnike upravljanja kreditnim rizikom i njihova evolucija i dalje traje. Upotreba pojedinih tehnika vremenom je postala jasno regulisana brojnim nacionalnim i međunarodnim propisima i dokumentima, pri čemu se po značaju izdvajaju oni koje je definisao Bazelski komitet. U revidiranom okviru merenja kapitala i definisanja kapitalnih standarda, poznatom kao Bazel II, navedena su dva pristupa za utvrđivanje zahteva za kapitalom za kreditni rizik: standardizovani pristup i pristup zasnovan na internim rejtinzima (BCBS, 2004). Kod standardizovanog pristupa, procenu kreditne sposobnosti dužnika vrše eksterne rejting agencije. U okviru pristupa, preporučeno je nekoliko efikasnih tehnika ublažavanja dejstva kreditnog rizika. Time je zaokružen set tehnika upravljanja kreditnim rizikom, gde spadaju (BCBS, 2004; Heffernan, 2005, str. 156-159; Van Greuning i Brajović Bratanović, 2006, str. 135166): politika odobravanja kredita, precizno utvrđivanje kamatne stope, limiti u kreditiranju, kolateral i garancija, sekjuritizacija i kreditni derivati, rezerve za kreditne gubitke i dr.

Politika odobravanja kredita podrazumeva podrobnu analizu zajmotražioca, jasno definisane kriterijume kreditiranja, adekvatno obezbeđenje potraživanja shodno rizičnosti plasmana, kontrolu plasiranih kredita i politiku upravljanja potencijalnim odstupanjima od ustanovljenih standarda (Van Greuning i Brajović Bratanović, 2006, str. 141) ili, pojednostavljeno, analizu kreditnih zahteva, nadzor nad plasiranim kreditima i prisilu, odnosno instrumente pritiska na zajmotražioca da ispuni preuzete obaveze (Visser, 2009, str. 86). Efikasna implementacija navedene procedure $\mathrm{u}$ islamskim bankama, skopčana je s brojnim izazovima i poteškoćama, naročito u slučaju vlasničkih ulaganja, mudarebe i mušareke. S obzirom na to da kod ovih ulaganja finansirani subjekt nema fiksnu obavezu prema banci i da postoji izražen problem asimetrične informisanosti, islamske banke moraju (Sarker, 1999, str. 20): sprovesti daleko rigorozniju analizu dobijenih zahteva za finansiranjem, nego što je to slučaj sa konvencionalnim bankama; vršiti konstantan nadzor nad realizacijom finansiranog projekta, zašta kod mudarebe postoje ograničene mogućnosti, zbog niskog nivoa kontrole koju finansijer (rabb ul-mal) ima nad finansiranim projektom; i inkorporirati različite instrumente obezbeđenja kojima treba izvršiti pritisak na finansiranog subjekta, što je, opet, ograničeno prirodom ovih ugovora, odnosno time što je banka partner, a ne poverilac. Iz tog razloga, islamske banke često zanemaruju preporuke teoretičara islamskog bankarstva, da svoje poslovanje baziraju na vlasničkim ulaganjima (Usmani, 2003, str. 23-80) i, bez obzira na njihovo negodovanje (Ayub, 2007, str. 213), najvećim delom ulaze $\mathrm{u}$ murabeha aranžmane finansiranja kupoprodaje (Iqbal, 2007, str. 5). Murabeha pruža mogućnost finansijeru da koristi daleko širi krug instrumenata obezbeđenja, nego $u$ slučaju vlasničkih ulaganja, poput: kolaterala, garancije (Usmani, 2003, str. 110-115) i avansne uplate (Khan \& Ahmed, 2001, str. 125). U instrumente prisile spadaju i penali za kašnjenje u otplati kredita. Uvećanje iznosa potraživanja prema dužniku zbog kašnjenja u otplati kredita, $\mathrm{u}$ islamskom bankarstvu nije dozvoljena, jer se uračunati višak smatra kamatom (El Gari, 2003, str. 19). Ipak, da odsustvo mogućnosti naplate penala ne bi ohrabrilo dužnike na kašnjenje, ponuđena je alternativna mogućnost, gde bi banke naplaćivale penale od nesavesnih dužnika radi njihovog kažnjavanja, a potom bi prikupljena suma bila uplaćena u humanitarne svrhe (Usmani, 2003, str. 121-123). U stabilnim pravnim i ekonomskim sistemima, primerena kazna nesavesnim zajmotražiocima bi moglo biti i njihovo stavljanje na crnu listu“, u koju bi uvid imale sve banke u sistemu i čime bi se faktički onemogućilo pomenutim subjektima da obezbede izvore finansiranja (Wilson, 2007).

Precizno utvrđena kamatna stopa je ona kamatna stopa koja banci omogućava pokriće troškova finansiranja, administrativnih troškova, premije rizika, shodno percipiranoj rizičnosti zajmotražioca, kao i ostvarivanje adekvatne stope profita (Heffernan, 2005, str. 156; Van Greuning i Brajović Bratanović, 2006, str. 138). Ukoliko, pak, banka plasira kredite po kamatnim stopama koje odstupaju od navedenog standarda, posledice mogu biti: 


\section{Applicability of the Conventional Credit Risk Management Techniques in Islamic Banking}

During the centuries of the conventional banking practice, numerous credit risk management techniques have been developed and their evolution has continued. The use of individual techniques has become clearly regulated by numerous national and international regulations and documents, the most significant being those defined by the Basel Committee. In the revised framework of capital measurement and definition of capital standards, known as Basel II, two approaches for determining the credit risk requirements are given: standardized approach and internal ratings-based approach (BCBS, 2004). In the standardized approach, the borrower's credit rating assessment is performed by the external rating agency. Within the framework of this approach, several effective techniques for mitigating the credit risk effects have been recommended. This completes the set of credit risk management techniques, which include: loan approval policy, precise determination of the interest rate, lending limits, collateral and guarantees, securitization and credit derivatives, loan loss provisions, etc. (BCBS, 2004; Heffernan, 2005, p. 156-159; Van Greuning \& Brajović Bratanović, 2006, p. 135-166).

The loan approval policy implies a detailed analysis of the borrower, the clearly defined lending criteria, the adequate securing of claims according to the placement riskiness, the control of the placed loans and the policy of managing potential deviations from the established standards (Van Greuning \& Brajović Bratanović, 2006, p. 141), or, simplified, the analysis of credit claims, the supervision of the placed loans and enforcement, or the instruments of pressure on the borrower to fulfill the undertaken obligations (Visser, 2009, p. 86). The effective implementation of the mentioned procedure in Islamic banks has been tied with numerous challenges and difficulties, especially in the case of equity investments, mudarabah and musharakah. Given that a financed entity in these investments does not have a fixed obligation towards the bank and that there is a conspicuous problem of asymmetric information, Islamic banks must (Sarker, 1999, p. 20): conduct a far more rigorous analysis of the funding claims than conventional banks; constantly monitor the implementation of the funded project, for which there are limited possibilities in mudarabah, due to the low level of control that the financier (rabb ul-mal) has over the funded project; and incorporate various security instruments that need to exert pressure on the financed entity, which is again limited by the nature of these contracts, given that the bank is a partner, not a creditor. For that reason, Islamic banks often ignore the recommendations of the Islamic banking theoreticians to base their business on equity investments (Usmani, 2003, p. 23-80) and, regardless of their disapproval (Ayub, 2007, p. 213), they predominantly enter the murabahah arrangements of financing the purchase of goods (Iqbal, 2007, p. 5). Murabahah provides the financier with the opportunity to use a much wider circle of security instruments than in case of equity investments, such as collateral, guarantees (Usmani, 2003, p. 110-115) and advance payments (Khan \& Ahmed, 2001, p. 125). The set of enforcement instruments also includes penalties for delay in loan repayment. Increasing the amount of claims against the debtor for his loan repayment delay is not allowed in Islamic banking because the included surplus is regarded as interest (El Gari, 2003, p. 19). However, the absence of the possibility to charge penalties can encourage borrowers to delay, so an alternative option has been offered, where banks would charge penalties from irresponsible debtors for their punishment, and then the collected sum would be paid for humanitarian purposes (Usmani, 2003, p. 121-123). In the stable legal and economic systems, an appropriate punishment for irresponsible borrowers could be their blacklisting, about which all banks in the system would be informed. This would, in fact, prevent the mentioned entities from accessing sources of finance (Wilson, 2007).

The precisely determined interest rate is the interest rate that allows the bank to cover the costs of financing, administrative costs, risk premium, according to the perceived riskiness of the borrower, and achieve the adequate profit margin (Heffernan, 2005, p. 156; Van Greuning \& Brajović Bratanović, 2006, p. 138). 
nepokrivenost troškova poslovanja, propušten profit, ali i, u slučaju previsokih kamatnih stopa, povlačenje sigurnih klijenata i smanjenje broja kvalitetnih projekata za finansiranje (Stiglitz \& Weiss, 1981, str. 393). U islamskom finansijskom sistemu još uvek ne postoji opšteprihvaćena referentna profitna stopa, iako postoje pokušaji njenog definisanja (Iqbal i Mirakhor, 2009, str. 209). Ključni razlog tome je nerazvijeno islamsko finansijsko tržište, sa nedovoljnom likvidnošću, brojem učesnika i transakcija, što je neadekvatna osnova za razvoj valjane referentne stope prinosa, od koje bi se polazilo prilikom definisanja cene finansiranja (El-Gamal, 2006, str. 79). Stoga, islamske banke uglavnom koriste LIBOR kao referentnu prinosnu stopu i dobrim delom slede konvencionalnu praksu definisanja cene finansiranja. Zbog toga su islamske banke predmet kritike šerijatskih stručnjaka, koji ovu praksu smatraju neprikladnom. S druge strane, deo šerijatskih stručnjaka smatra da sama upotreba tržišnih kamatnih stopa kao referentnih vrednosti i indikatora prinosa, nije u koliziji sa šerijatskim propisima, ali da, ipak, tu praksu treba napustiti čim se za to steknu uslovi (Usmani, 2003, str. 102-104).

Dejstvo kreditnog rizika može biti značajno ublaženo ograničavanjem kreditnih pozicija. Svestan te činjenice, Bazelski komitet (BCBS, 1991) je definisao standarde visoke izloženosti prema jednom klijentu, grupi povezanih klijenata, klijentima povezanih s bankom, geografskim područjima i privrednim granama. Preporuke Bazelskog komiteta usvojile su i islamske banke, i to je jedan od bitnijih elemenata njihove politike upravljanja kreditnim rizikom (Van Greuning \& Iqbal, 2008, str. 121).

Kolateral je jedan od najstarijih instrumenata upravljanja kreditnim rizikom, sa dugom tradicijom implementacije i $\mathrm{u}$ islamskom bankarstvu. Prilažući valjan kolateral, zajmotražilac pokazuje svoju ekonomsku snagu, ali i posvećenost finansiranom projektu i čvrsto verovanje u njegov uspeh (Bebczuk, 2003, str. 22-23). Ipak, u fokusu pažnje banke treba da bude poslovni potencijal finansiranog projekta, a ne sredstva kojim se garantuje vraćanje zajma. U suprotnom, banka će doći u situaciju da finansira isključivo imućne zajmotražioce, koji su u mogućnosti da prilože kolateral visoke vrednosti, ali su i često skloniji rizičnim ulaganjima nego ostali zajmotražioci, što će na kraju rezultirati zanemarivanjem perspektivnih poslovnih poduhvata i povećanjem udela visokorizične aktive (Stiglitz \& Weiss, 1981, str. 402). Kad govorimo o islamskim bankama, upotreba kolaterala u obezbeđivanju plasmana je veoma raširena, ali postoje i izvesna ograničenja (Khan \& Ahmed, 2001, str. 118120): proo, kao kolateral se ne mogu koristiti kvarljive i haram robe, potraživanja od trećeg lica i kamatonosne hartije od vrednosti, koje se zbog svoje likvidnosti i utrživosti često koriste kao kolateral u konvencionalnoj bankarskoj praksi, i drugo, zemlje u kojima islamske banke pretežno posluju, nemaju razvijeno tržište za laku i troškovno efikasnu prodaju preuzetog kolaterala. Takođe, upotreba kolaterala kod najrizičnijih islamskih bankarskih poslova, mudarebe i mušareke, je često nemoguća, jer je kod njih uspostavljen partnerski, a ne dužničkopoverilački odnos između finansiranog subjekta i banke (Abedifar, Molyneux \& Tarazi, 2013, str. 2037). Pored kolaterala, i upotreba garancije je šerijatski dozvoljena, pod uslovom da garanciju pruža treća strana i da provizija koju banka naplaćuje klijentima za uslugu pružanja garancije, ne bude veća od troškova koje je banka podnela pružajući navedenu uslugu (Khan \& Ahmed, 2001, str. 121; Usmani, 2003, str. 113).

Sekjuritizacija je proces nastao kao rezultat finansijskog inženjeringa, koji doživeo dinamičan rast u poslednjih nekoliko decenija. Zahvaljujući sekjuritizaciji, bankama je omogućeno daleko aktivnije upravljanje kreditnim portfoliom, bolje korišćenje tržišnih mogućnosti, ostvarenje većeg profita i efikasnije upravljanje rizikom $\mathrm{i}$ kapitalom. $S$ druge strane, zloupotreba ovog procesa od strane pojedinih banaka, koje su sekjuritizaciju koristile za svoje beskrupulozne špekulativne aktivnosti, značajno je doprinela pokretanju, najpre hipotekarne, a kasnije i globalne finansijske krize, nakon čega je javnost postala svesna opasnosti koje manipulisanje ovim procesom može da izazove (Kane, 2009; Fligstein \& Goldstein, 2010; Martin, 2010; Piskorski, Seru \& Vig, 2010). Sekjuritizacija je našla primenu i u islamskom bankarstvu, čemu su dokaz sukuk obveznice, koje su razvijene upravo kroz proces sekjuritizacije (Ayub, 2007, str. 393). Ipak, konvencionalni oblik sekjuritizacije 
If, however, the bank places loans at the interest rates that deviate from the stated standard, the consequences may be: the uncovered costs of business, the ungained profit, but also, in case of excessive interest rates, the withdrawal of certain clients and the reduction in the number of quality projects for financing (Stiglitz \& Weiss, 1981, p. 393). In the Islamic financial system, there is still no generally accepted benchmark profit rate, although there have been some attempts to define it (Iqbal \& Mirakhor, 2009, p. 209). The key reason for this is the underdeveloped Islamic financial market, with insufficient liquidity, number of participants and transactions, being an inadequate basis for the development of a valid benchmark rate, which would be the basis for defining the financing price (El-Gamal, 2006, p. 79). Therefore, Islamic banks mostly use LIBOR as the reference yield rate and, to a great extent, follow the conventional practice of defining the financing price. As a result, Islamic banks are subject to criticism by Shariah experts who consider this practice inappropriate. On the other hand, some Shariah experts find that the use of market interest rates as reference values and yield indicators is not in conflict with the Shariah regulations, but that, nevertheless, this practice should be abandoned as soon as the conditions are met (Usmani, 2003, p. 102-104).

The effect of credit risk can be significantly mitigated by the limitation of credit positions. Aware of this fact, the Basel Committee (BCBS, 1991) has defined the high-level exposure standards for a single client, a group of related clients, clients connected with the bank, geographical areas and business branches. The recommendations of the Basel Committee have also been adopted by Islamic banks, and this is one of the most important elements of their credit risk management policy (Van Greuning \& Iqbal, 2008, p. 121).

Collateral is one of the oldest credit risk management instruments, with a long tradition of implementation in Islamic banking. By attaching a valid collateral, the borrower shows his economic strength, but also the commitment to the funded project and a firm belief in its success (Bebczuk, 2003, p. 22-23). However, the focus of the bank's attention should be on the funded project's business potential, and not on the assets by which the loan repayment is guaranteed. Otherwise, the bank will come into the situation to finance exclusively wealthy borrowers who are able to provide high-value collateral, although they are often more inclined to risky investments than other borrowers, which will ultimately result in neglecting the prospective business ventures and increasing the share of high risk assets (Stiglitz \& Weiss, 1981, p. 402). Speaking of Islamic banks, the use of collateral in securing placements is very widespread, but there are some limitations (Khan \& Ahmed, 2001, p. 118-120): firstly, as a collateral, one cannot use perishables and haram goods, receivables from third parties and interest-bearing securities, which, because of their liquidity and marketability, are often used as collateral in conventional banking practices, and secondly, the countries in which Islamic banks predominantly do business, do not have a developed market for the easy and cost-effective sale of the collaterals. Also, the use of collaterals in the riskiest Islamic banking businesses, mudarabah and musharakah, is often impossible, because there is an established partnership rather than a debtor-creditor relationship between the funded entity and the bank (Abedifar, Molyneux \& Tarazi, 2013, p. 2037). In addition to the collateral, the use of the guarantee is also Shariah allowed, under the condition that the guarantee is provided by a third party and that the fee charged by the bank to the clients for the guarantee service is not higher than the costs borne by the bank providing the mentioned service (Khan \& Ahmed, 2001, p. 121; Usmani, 2003, p. 113).

Securitization is a process that has emerged as a result of financial engineering, which has experienced a dynamic growth in the last few decades. Thanks to securitization, banks have been enabled to more actively manage the loan portfolio, better utilize the market opportunities, achieve greater profits and conduct risk and capital management more efficiently. On the other hand, the abuse of this process by some banks which have used securitization for their unscrupulous speculative activities significantly contributed to the outbreak of, first, mortgage and later global financial crisis, after which the public became aware of the dangers that manipulation 
u islamskom bankarstvu nije primenjiv, jer šerijatski propisi zabranjuju prodaju potraživanja (Khan \& Ahmed, 2001, str. 123), osim po nominalnoj vrednosti (El Gari, 2003, str. 20). Kad je reč o finansijskim derivatima, konvencionalne banke imaju raspolaganju više vrsta ovih instrumenata za potrebe upravljanja kreditnim rizikom, s tim što najviše koriste svop kreditnog rizika (credit default swap) (British Bankers' Association, 2006, str. 6). Islamske banke, pak, većinu finansijskih derivata $u$ njihovoj tradicionalnoj formi ne mogu koristiti (Sundararajan \& Errico, 2002, str. 6), jer ovi instrumenti sadrže šerijatom zabranjene elemente, poput: kamate, visoke neizvesnosti, špekulacije i igre sa nultim ishodom (Khan, Muntaqua \& Samad, 2008, str. 205). Međutim, u situaciji kada islamske banke raspolažu veoma ograničenim setom instrumenata za upravljanje kreditnim rizikom, upotrebu finansijskih derivata ne treba a priori odbaciti. Štaviše, neophodno je razvijati šerijatski prihvatljive derivate, $\mathrm{u}$ vidu hedžing instrumenata bez šerijatski zabranjenih elemenata, putem kojih bi se isključivo realizovala stvarna razmena predmeta ugovora (Jobst, 2007, str. 28).

Rezerve za kreditne gubitke nezaobilazni su deo konvencionalne politike upravljanja kreditnim rizikom. U pitanju je značajna mera opreza koja sputava banke u njihovoj težnji da finansiranjem rizičnih projekata ostvare dodatni profit, jer, shodno rizičnosti plasmana, ograničava njihov investicioni potencijal (detaljnije o rezervama za kreditne gubitke Docking, Hirschey \& Jones, 1997; Ahmed, Takeda \& Thomas, 1999; Ng \& Roychowdhury, 2014). Konvencionalne banke vrše klasifikaciju svojih plasmana prema rizičnosti i međunarodnim standardima $u$ pet kategorija: standardna aktiva, aktiva koja zahteva posebnu pažnju, supstandardna aktiva, sumnjiva i sporna potraživanja i gubitak, pri čemu je za svaku kategoriju određena visina rezervi, u vidu procenta od iznosa plasmana, koja varira u skladu sa rizičnošću plasmana (Van Greuning i Brajović Bratanović, 2006, str. 161-162, 165). S druge strane, $\mathrm{u}$ islamskom bankarstvu ne postoji praksa formiranja rezervi za kreditne gubitke u njihovom konvencionalnom obliku, već se formiraju rezerve za izjednačavanje dobiti i rezerve rizika ulaganja (Boulila Taktak, Ben Slama Zouari \&
Boudriga, 2010, str. 124). Tu praksu je prva uvela Jordan Islamic Bank, a danas je sprovode brojne islamske banke $\mathrm{u}$ cilju zaštite akcionara i deponenata, čijim sredstvima se ove rezerve i formiraju (Khan \& Ahmed, 2001, str. 123). Sam proces formiranja smatra se kontroverznim i meta je čestih kritika zbog upitne usklađenosti sa principima islamskog bankarstva, kao $\mathrm{i}$ potencijalnog favorizovanja akcionara $\mathrm{i}$ vlasnika velikih i dugoročnih investicionih depozita (Khan \& Ahmed, 2001, str. 123; Iqbal i Mirakhor, 2009, str. 224-226).

Pristup zasnovan na internim rejtinzima javlja se u dve varijante: osnovni i napredni. Uvođenjem ovog pristupa, data je prilika bankama koje raspolažu adekvatnim finansijskim, tehničkim i kadrovskim kapacitetima da same procenjuju kreditnu sposobnost dužnika i verovatnoću neizmirenja obaveza (BCBS, 2004). U finansijskoj teoriji i praksi razvijeni su brojni modeli, poput Z-score modela (Altman, 1968), KMV modela (baziran na Black \& Scholes, 1973; Merton, 1973, 1974) i CreditMetrics modela (J. P. Morgan, 1997), pomoću kojih su banke mogle proceniti kreditnu sposobnost svog klijenta. Bazel II je, u suštini, samo prepoznao potrebe velikih banaka i njihove mogućnosti da same utvrđuju verovatnoću neizmirenja obaveza. Dobar deo islamskih banaka ne raspolaže potrebnim kapacitetima za efikasnu primenu ovog pristupa utvrđivanju zahteva za kapitalom za kreditni rizik. Ipak, teoretičari islamskog bankarstva su se bavili ovom temom i testirali primenu pristupa zasnovanog na internim rejtinzima u islamskim bankama (vidi Akkizidis \& Khandelwal, 2008, str. 118-132).

\section{Praksa upravljanja kreditnim rizikom $u$ islamskim bankama}

Kreditni rizik se smatra najvažnijim rizikom $\mathrm{u}$ konvencionalnom bankarstvu. S druge strane, istraživanja su pokazala da islamske banke najznačajnijim rizikom smatraju rizik promene marže (pandan kamatnom riziku u konvencionalnom bankarstvu), potom operativni, likvidnosni, kreditni i tržišni rizik (Khan \& Ahmed, 2001, str. 61), iako je kreditni rizik glavni uzrok većine poslovnih neuspeha islamskih banaka (Bourakba \& Zerargui, 2015, 
of this process could cause (Kane, 2009; Fligstein \& Goldstein, 2010; Martin, 2010; Piskorski, Seru \& Vig, 2010). Securitization has also been applied in Islamic banking, exemplified by the sukuk bonds, which have been developed only through the securitization process (Ayub, 2007, p. 393). However, the conventional form of securitization in Islamic banking is inapplicable, since Shariah regulations prohibit the sale of receivables (Khan \& Ahmed, 2001, p. 123), except at nominal value (El Gari, 2003, p. 20). When it comes to financial derivatives, conventional banks at their disposal have several types of these instruments for the credit risk management purposes, the most used being the credit default swap (British Bankers' Association, 2006, p. 6). Islamic banks, however, cannot use most of the financial derivatives in their traditional form (Sundararajan \& Errico, 2002, p. 6), because these instruments contain Shariah prohibited elements such as: interest, high uncertainty, speculation and zero-sum games (Khan, Muntaqua \& Samad, 2008, p. 205). However, in a situation where Islamic banks have a very limited set of credit risk management instruments, the use of financial derivatives should not be a priori avoided. Moreover, it is necessary to develop Shariahacceptable derivatives, in the form of hedging instruments without Shariah-prohibited elements, through which the real exchange will be realized (Jobst, 2007, p. 28).

Loan loss provisions are an indispensable part of the conventional credit risk management policy. They are an important precautionary measure that restrains banks in their tendency to generate additional profits by financing risky projects, because, according to the riskiness of their placements, they limit the banks' investment potential (more about loan loss provisions in Docking, Hirschey \& Jones, 1997; Ahmed, Takeda \& Thomas, 1999; Ng \& Roychowdhury, 2014). Conventional banks carry out the classification of their placements according to riskiness and international standards into five categories: standard assets, assets that require special attention (watch assets), substandard assets, doubtful and disputed receivables and losses, each category incurring the specific amount of provisions determined as a percentage of the amount of placements, which varies depending on the placements' riskiness (Van Greuning \& Brajović Bratanović, 2006, p. 161-162, 165). On the other hand, in Islamic banking, there is no practice of forming loan loss provisions in their conventional form, although profit equalization reserves and investment risk reserves do exist (Boulila Taktak, Ben Slama Zouari \& Boudriga, 2010, p. 124). This practice was first introduced by the Jordan Islamic Bank, and today it is conducted by numerous Islamic banks in order to protect shareholders and depositors, whose funds are used to form these reserves (Khan \& Ahmed, 2001, p. 123). The formation process itself is considered to be controversial and it is a target of frequent criticism due to its questionable compliance with the principles of Islamic banking, as well as the potential favoring of shareholders and owners of large and longterm investment deposits (Khan \& Ahmed, 2001, p. 123; Iqbal \& Mirakhor, 2009, p. 224-226).

The internal ratings-based approach comes in two variants: foundation and advanced. By introducing this approach, an opportunity has been given to banks that have the adequate financial, technical and personnel capacities to assess the creditworthiness of the debtor and the probability of his default (BCBS, 2004). In financial theory and practice, numerous models have been developed, such as the Z-score model (Altman, 1968), the KMV model (based on Black \& Scholes, 1973, Merton, 1973, 1974) and the CreditMetrics model (J. P. Morgan, 1997) by which banks could assess the creditworthiness of their client. Basel II has, in essence, only recognized the needs of large banks and their ability to determine the likelihood of default. A large proportion of Islamic banks do not have the necessary capacity to effectively apply this approach to determining the credit risk capital requirements. However, the theoreticians of Islamic banking have dealt with this topic and tested the application of internal ratings-based approach in Islamic banks (see Akkizidis \& Khandelwal, 2008, p. 118-132).

\section{Credit Risk Management Practice in Islamic Banks}

Credit risk is considered the most important risk in conventional banking. On the other hand, research has shown that Islamic banks 
str. 69). Razlog ovakve percepcije je dominacija murabeha ulaganja $\mathrm{u}$ aktivi islamskih banaka, kao najmanje rizičnog islamskog finansijskog instrumenta (Khan \& Ahmed, 2001, str. 62), ali i instrumenta kod kojeg je dejstvo rizika promene marže snažnije od dejstva kreditnog rizika (Bourakba \& Zerargui, 2015, str. 69).

Analizom okvira upravljanja kreditnim rizikom $u$ više islamskih banaka (Abu Dhabi Islamic Bank, Al Rajhi Bank, Bahrain Islamic Bank, Dubai Islamic Bank, Qatar Islamic Bank), utvrdili smo da oni uključuju sledeće tehnike ublažavanja dejstva kreditnog rizika: utvrđivanje maksimalne izloženosti kreditnom riziku, izloženosti geografskim područjima i privrednim granama, izloženosti klijentima različitih rejtinga, izloženosti plasmanima sa različitom veličinom kašnjenja u plaćanju, zatim raspoloživi kolateral u različitim formama i oduzeti kolateral nakon neplaćanja ugovorenih iznosa od strane dužnika, i politiku otpisa potraživanja. Drugo, iz finansijskih izveštaja posmatranih banaka, može se uočiti da u aktivi dominiraju pojedine vrste plasmana, kao i da postoji visoka izloženost pojedinim geografskim područjima, što vodi jačanju dejstva rizika koncentracije. Na primer, kod Qatar Islamic Bank na finansijsku aktivu (u okviru koje najveće učešće imaju murabeha plasmani) otpada blizu 65\% ukupne kreditne izloženosti banke, dok je, mereno HH indeksom (Herfindahl-Hirschman Index), koncentracija plasmana $44,79 \%$. U istoj banci, skoro kompletna kreditna izloženost je vezana za region Bliskog istoka (91\%), pa je samim tim i tu ostvaren visok stepen koncentracije plasmana $(83,62 \%)$.

Kad je reč o kreditnoj izloženosti islamskih banaka pojedinim privrednim sektorima, najveće učešće ima finansiranje kupovine trajnih potrošačkih dobara (27\%), slede finansiranje kupovine nekretnina i izgradnje (16\%), poslovi sa drugim bankama i finansijskim institucijama (15\%), finansiranje proizvodnje (12\%) i trgovine (8\%) i dr. (Islamic Development Bank Group \& World Bank Group, 2016, str. 65). Na osnovu datih podataka, utvrdili smo da koncentracija plasmana islamskog bankarskog sektora iznosi $17,2 \%$. S druge strane, udeo neperformansnog finansiranja u ukupnom finansiranju, kao jedan od najvažnijih pokazatelja efikasnosti upravljanja kreditnim rizikom u banci, je tokom poslednjih nekoliko godina značajno varirao. U trenutku pojave svetske ekonomske krize 2008. godine, ovaj pokazatelj je imao vrednost 3,85\%, najveću vrednost je dostigao 2010. godine (blizu $6 \%$ ), da bi već 2014 . godine njegova vrednost bila ispod one koju imao pre pojave krize (2.8\%) (IFSB, 2016, str. 93-94). Kad je kapitalizovanost u pitanju, kao odraz otpornosti banaka na dejstvo rizika i kriza, kod islamskih banaka su zabeleženi sledeći prosečni rezultati adekvatnost ukupnog kapitala je 15,79\%, a nivoa 1 kapitala 13,89\% (IFSB, 2016, str. 94). Dostignuti nivo kapitalizovanosti islamskih banaka daleko prevazilazi zahteve Bazela III (BCBS, 2010). Međutim, tokom poslednjih nekoliko godina zabeleženo je smanjenje kapitalizovanosti islamskih banaka, što uglavnom nije posledica smanjenja raspoloživog kapitala, već opreznijeg i uspešnijeg ulaganja, kao i snažnije podrške monetarnih vlasti islamskim bankama (IFSB, 2016, str. 94).

Intenzitet dejstva kreditnog rizika u islamskom bankarstvu uslovljen je brojnim faktorima, od kojih pojedini podjednak uticaj imaju i u konvencionalnom bankarstvu, dok su ostali specifični za islamsko bankarstvo. Ključni specifični faktori, koji utiču na dejstvo svih rizika sa kojima se islamske banke suočavaju, su zahtevi za usklađenošću poslovanja sa šerijatskim propisima i tim zahtevima određena priroda islamskih finansijskih instrumenata, kao i disharmonija standarda i propisa vezanih za islamsko bankarstvo, među različitim zemljama (Bhatti \& Misman, 2010, str. 20). Time se stvara potreba za posebnom politikom, regulacijom i tehnikama kontrole rizika (Abedifar, Molyneux \& Tarazi, 2013, str. 2072-2073). Kreditni rizik nije izuzetak, s tim što za dobijanje realne slike o njegovoj uslovljenosti u islamskom bankarskom poslovanju, neophodno je izvršiti dublju analizu i predstaviti faktore koji isključivo ili najvećim delom pokreću dejstvo ovog rizika. Najvažniji specifični faktori kreditnog rizika u islamskom bankarstvu su: specifična struktura plasmana i izvora, veličina banke, religioznost klijenata, upravljačka i vlasnička struktura, kao i dostupnost tehnika za upravljanje kreditnim rizikom.

Struktura plasmana islamskih banaka, sa dominantnim učešćem murabeha ulaganja, odstupa od preporuka šerijatskih stručnjaka, 
consider the most significant risk to be the mark-up risk (a counterpart of the interest rate risk in conventional banking), followed by operational, liquidity, credit and market risk (Khan \& Ahmed, 2001, p. 61), although credit risk is the main cause of most business failures of Islamic banks (Bourakba \& Zerargui, 2015, p. 69). The reason for this perception is the dominance of murabahah investment in the assets of Islamic banks, as the least risky Islamic financial instrument (Khan \& Ahmed, 2001, p. $62)$, but also the instrument in which the markup risk effect is more powerful than the credit risk effect (Bourakba \& Zerargui, 2015, p. 69).

By analyzing the credit risk management framework in several Islamic banks (Abu Dhabi Islamic Bank, Al Rajhi Bank, Bahrain Islamic Bank, Dubai Islamic Bank, Qatar Islamic Bank), we have found that they included the following credit risk mitigation techniques: identifying the maximum exposure to credit risk, the exposure to geographic areas and economic branches, the exposure to clients of different ratings, the exposure to placements with different amounts of delay in payment, the available collateral in various forms and collateral seized after debtor's default, and the policy of writing-off receivables. Secondly, the financial reports of the observed banks show that certain types of placements dominate the asset, as well as that there is a high exposure to certain geographical areas, which leads to the strengthening of the concentration risk effect. For example, in Qatar Islamic Bank financial assets (the main share of which is held by murabahah placements), account for almost $65 \%$ of the total credit exposure of banks, while the concentration of placements amounts to $44.79 \%$, measured by the $\mathrm{HH}$ index (Herfindahl-Hirschman Index). In the same bank, almost entire credit exposure is related to the region of the Middle East (91\%), and consequently there is a high degree of concentration of placements (83.62\%).

When it comes to the credit exposure of Islamic banks to individual economic sectors, the largest share has been held by financing the purchase of durable consumer goods (27\%), followed by financing the purchase of real estate and construction (16\%), transactions with other banks and financial institutions (15\%), financing production (12\%) and trade (8\%) and other (Islamic Development Bank Group \& World Bank Group, 2016, p. 65). Analyzing the data, we have found that the concentration of placements in the Islamic banking sector amounts to $17.2 \%$. On the other hand, the share of non-performing financing in total financing, as one of the most important indicators of the efficiency of credit risk management in a bank, has varied considerably over the last few years. At the time of the global economic crisis in 2008, this indicator had a value of $3.85 \%$, its peek being reached in 2010 (close to 6\%), and in 2014 it was below its pre-crisis value $(2.8 \%)$ (IFSB, 2016, p. 93-94). When it comes to capitalization, as a reflection of the banks' resilience to the effects of risks and crises, the following average results have been recorded in Islamic banks: total capital adequacy was $15,79 \%$ and Tier 1 capital was 13,89\% (IFSB, 2016, p. 94). The achieved level of capitalization of Islamic banks goes far beyond the requirements of Basel III (BCBS, 2010). However, over the past few years there has been a decrease in the capitalization of Islamic banks, which is mostly not the result of a reduction in available capital, but of a more cautious and successful investment, as well as the stronger monetary authorities' support for Islamic banks (IFSB, 2016, p. 94).

The intensity of the credit risk effects in Islamic banking is conditioned by a number of factors, some of which have similar impacts in conventional banking, while others are specific to Islamic banking. The key specific factors influencing the effects of all the risks faced by Islamic banks are the requirements for compliance with Shariah regulations and the nature of Islamic financial instruments determined by those requirements, as well as the discrepancies among the standards and regulations related to Islamic banking in different countries (Bhatti \& Misman, 2010, p. 20). This creates the need for the specific policy, regulation and risk control techniques (Abedifar, Molyneux \& Tarazi, 2013, p. 20722073). Credit risk is not an exception, but in order to obtain a realistic picture of its conditionality in Islamic banking business, it is necessary to conduct a deeper analysis and present the factors that exclusively, or to a large extent, trigger the effects of this risk. The most important specific credit risk factors in 
koji smatraju da se poslovanje islamskih banaka mora bazirati na vlasničkim ulaganjima. Međutim, ovaj tip ulaganja islamske banke percipiraju kao najrizičniji (Khan \& Ahmed, 2001, str. 62), zbog izražene asimetrične informisanosti ugovornih strana (Ben Khediri \& Ben-Khedhiri, 2009, str. 414), složenosti ovih aranžmana, snažnog prisustva moralnog hazarda, ograničene mogućnosti korišćenja penala u slučaju neuspeha finansiranog projekta (Abedifar, Molyneux \& Tarazi, 2013, str. 2048), kao i nemogućnosti da se potvrdi default sve do okončanja ugovora (Sundararajan \& Errico, 2002, str. 4-5). Istraživanja su pokazala da rast udela vlasničkih ulaganja u aktivi islamskih banaka povećava njihovu izloženost dejstvu kreditnog rizika (Ahmad \& Ahmad, 2004, str. 76) i da udeo neperformansnih plasmana raste sa rastom udela vlasničkog ulaganja (Abusharbeh, 2014, str. 145). Rast udela murabehe, kao daleko sigurnijeg plasmana (How, Karim \& Verhoeven, 2005, str. 78), pak, ima suprotno dejstvo (Abusharbeh, 2014, str. 146). Ipak, ne treba zanemariti činjenicu da je napravljen izvestan napredak $\mathrm{u}$ efikasnosti upravljanja kreditnim rizikom vlasničkih ulaganja (Shaikh \& Jalbani, 2009, str. 77-78).

Najvažniji izvor finansiranja islamskih banaka su investicioni depoziti, koji u ukupnim depozitima islamskih banaka učestvuju sa 44.11\% (IFSB, 2016, str. 96). Ovi depoziti su specifični po tome što su njihovi vlasnici partneri, a ne poverioci banke, jer je prinos na njihove uloge uslovljen poslovnim uspehom banke (detaljnije Van Greuning and Iqbal, 2008, str. 193-196). Ta okolnost ublažava negativne posledice dejstva kreditnog rizika na poslovanje islamskih banaka jer postoji mogućnost prenosa tereta kreditnog rizika na investicione deponente (Sundararajan \& Errico, 2002, str. 4; How, Karim \& Verhoeven, 2005, str. 79; Abedifar, Molyneux \& Tarazi, 2013, str. 2062). Upravo ta činjenica se često zanemaruje kada se određuju zahtevi za kapitalom kod pojedinih plasmana islamskih banaka. To je naročito izraženo kod vlasničkih ulaganja, gde su neretko zahtevi za kapitalom neumereno visoki, čime se dodatno destimuliše ovaj tip ulaganja (Khan, 2006, str. 406). Međutim, priroda investicionih depozita i njihovo visoko učešće u izvorima finansiranja islamskih banaka može imati i negativne posledice. Islamske banke, $\mathrm{u}$ ovim okolnostima, mogu biti podstaknute na rizična ulaganja koja nisu adekvatno pokrivena kapitalom (Sundararajan \& Errico, 2002, str. 6). Toga su svesni i sami vlasnici investicionih depozita, pa stoga pred banke postavljaju jasna profitna očekivanja, u slučaju čijeg neispunjenja oni povlače svoje uloge, zbog čega islamske banke moraju sprovoditi detaljnu kreditnu analizu prilikom svakog plasmana (How, Karim \& Verhoeven, 2005, str. 79) i formirati, već pomenute, rezerve za osiguranje prinosa (Iqbal i Mirakhor, 2009, str. 224-226). Stoga, visok udeo investicionih depozita u izvorima finansiranja može dodatno disciplinovati islamske banke, jer neodgovorno poslovanje banke može dovesti do povlačenja ovih depozita (Abedifar, Molyneux \& Tarazi, 2013, str. 2072).

Dejstvo kreditnog rizika $\mathrm{u}$ islamskim bankama uslovljeno je i veličinom njihove aktive. Rast aktive direktno proporcionalno utiče na rast izloženosti dejstvu kreditnog rizika (Bourakba \& Zerargui, 2015, str. 72). Jedan od razloga za to je izraženija averzija prema riziku kod malih islamskih banaka u poređenju sa velikim islamskim bankama, i s tim povezan viši nivo njihove kapitalizovanosti (Abedifar, Molyneux \& Tarazi, 2013, str. 2039). Drugo, rastom aktive banke, smanjuje se zastupljenost religioznih klijenata, jer se fokus usmerava na ekonomski moćnije klijente i institucije za koje religioznost ima manji značaj (Abedifar, Molyneux \& Tarazi, 2013, str. 2062-2063). Religioznost je u ovom kontekstu bitna jer podstiče na ispunjavanje preuzetih obaveza, čime se ublažava dejstvo kreditnog rizika na poslovanje islamskih banaka (Abedifar, Molyneux \& Tarazi, 2013, str. 2048).

Vlasnička i upravljačka struktura islamskih banaka, takođe, utiču na intenzitet dejstva kreditnog rizika. Istraživanja su pokazala da decentralizacija upravljanja (povećanje broja upravljačkih i regulatornih tela, brojnosti njihovog članstva, udela nezavisnih članova i broja članova šerijatskih odbora) i niska koncentracija vlasništva (udeo glavnih akcionara u vlasništvu), ublažava dejstvo kreditnog rizika, jer vodi transparentnijem i odgovornijem poslovanju (Bourakba \& Zerargui, 2015, str. 72). Tu posebno treba istaći značaj šerijatskih odbora, koji mogu imati 
Islamic banking are: the especific structure of placements and sources, the size of the bank, the client's religiousness, the management and ownership structure, as well as the availability of credit risk management techniques.

The structure of placements of Islamic banks, with the dominant share of murabahah investment, deviates from the recommendations of Shariah experts, who consider that the operation of Islamic banks must be based on equity investments. However, Islamic banks perceive this type of investment as the most risky (Khan \& Ahmed, 2001, p. 62), due to the conspicuous asymmetric information (Ben Khediri \& Ben-Khedhiri, 2009, p. 414), the complexity of these arrangements, the strong presence of moral hazard (Abedifar, Molyneux \& Tarazi, 2013, p. 2048), as well as the inability to confirm the default until the end of the contract (Sundararajan \& Errico, 2002, p. 4-5). Researches have shown that the increase in the share of equity investments in the assets of Islamic banks increases their exposure to credit risk (Ahmad \& Ahmad, 2004, p. 76) and that the share of non-performing loans increases with the increase in the share of equity investments (Abusharbeh, 2014, p. 145). The growth in the share of murabahah, as a far more secure placement (How, Karim \& Verhoeven, 2005, p. 78), on the other hand, has the opposite effect (Abusharbeh, 2014, p. 146). However, one should not neglect the fact that some progress has been made in the efficiency of credit risk management of equity investments (Shaikh \& Jalbani, 2009, p. 77-78).

The most important source of funding for Islamic banks are investment deposits, which account for $44.11 \%$ in total deposits of Islamic banks (IFSB, 2016, p. 96). These deposits are specific in that their owners are partners and not creditors of the bank, because the return on their deposits is conditioned by the bank's business success (more in Van Greuning \& Iqbal, 2008, p. 193-196). This circumstance mitigates the negative consequences of the credit risk effect on the operations of Islamic banks, because there is a possibility of transferring the credit risk burden onto the investment depositors (Sundararajan \& Errico, 2002, p. 4; How, Karim \& Verhoeven, 2005, p. 79; Abedifar, Molyneux \& Tarazi, 2013, p. 2062).
This fact is often ignored when determining the capital requirements for certain placements of Islamic banks. This is particularly evident in the case of equity investments, where capital requirements are often too high, which additionally discourages this type of investment (Khan, 2006, p. 406). However, the nature of investment deposits and their high share in sources of financing of Islamic banks may have some negative consequences. Islamic banks can, in these circumstances, be encouraged to take risk ventures that are not adequately covered by capital (Sundararajan \& Errico, 2002, p. 6). Being aware of this, investment deposit holders set the clear profit expectations in front of the banks, and if the banks fail in fulfilling those expectations, they withdraw their deposits, which is why Islamic banks have to conduct a detailed credit analysis for each of the placements (How, Karim \& Verhoeven, 2005, p. 79) and to allocate the already mentioned provisions for securing the yield (Iqbal \& Mirakhor, 2009, p. 224-226). Therefore, a high proportion of investment deposits in funding sources can further discipline Islamic banks, because any irresponsible bank operations can lead to the withdrawal of these deposits (Abedifar, Molyneux \& Tarazi, 2013, p. 2072).

The credit risk effect in Islamic banks is also conditioned by the size of their assets. The growth of assets is directly proportional to the growth of exposure to credit risk (Bourakba \& Zerargui, 2015 , p. 72). One of the reasons for this is a more conspicuous risk aversion of small Islamic banks compared to large Islamic banks, and with this associated higher level of their capitalization (Abedifar, Molyneux \& Tarazi, 2013, p. 2039). Second, the growth of bank assets reduces the share of religious clients, since the focus is shifted to the financially more powerful clients and institutions for whom religion is less important (Abedifar, Molyneux \& Tarazi, 2013, p. 20622063). Religiousness is important in this context because it encourages the fulfillment of the undertaken commitments, which mitigates the credit risk effect on the Islamic banks' business (Abedifar, Molyneux \& Tarazi, 2013, p. 2048).

The ownership and management structure of Islamic banks also affects the intensity of the credit risk effects. Researches have shown that the decentralization of governance 
ključnu ulogu u disciplinovanju islamskih banaka, ukoliko su u svom radu nezavisni, imaju dovoljan uticaj u organizaciji i dovoljan broj članova sa adekvatnom stručnošću (Farook \& Lanis, 2007, str. 240-241).

Efikasno upravljanje kreditnim rizikom nije moguće bez postojanja adekvatnog okvira, kojim treba da se definišu instrumenti i propisi vezani za upravljanje kreditnim rizikom. Tokom poslednjih nekoliko decenija, islamske banke i međunarodne islamske finansijske regulatorne institucije su radile na razvijanju takvog okvira, koji bi mogao da odgovori potrebama i zahtevima islamskih banaka. Međutim, postignuti rezultati su nezadovoljavajući, jer islamskim bankama i dalje na raspolaganju stoji mali broj šerijatski usklađenih, autentičnih tehnika ublažavanja kreditnog rizika, zbog čega su one primorane da koriste konvencionalne tehnike (Sundararajan \& Errico, 2002, str. 6; Nazir, Daniel \& Nawaz, 2012, str. 121). Stoga, jedan od prioritetnih zadataka islamskih banaka je snažnije angažovanje na polju islamskog finansijskog inženjeringa i inovacija, kako bi se ublažila rizičnost postojećih islamskih finansijskih aranžmana i razvile nove tehnike upravljanja rizicima (Khan, 2006, str. 406407; Nazir, Daniel \& Nawaz, 2012, str. 121). Ovaj proces ometa još uvek prisutna dilema, da li ipak oponašati konvencionalne banke $u$ upravljanju kreditnim rizikom, iako je jasno da, zbog bitnih razlika između ova dva tipa finansijskih institucija, to nije moguće raditi na efikasan način (Boumediene, 2010, str. 27).

$\mathrm{Na}$ kraju, ne treba zanemariti ni uticaj makroekonomskih faktora na kreditni rizik $\mathrm{u}$ islamskom bankarstvu (Waemustafa \& Sukri, 2015), iako to nije specifikum islamskog bankarstva. Uticaj ovih faktora posebno je došao do izražaja u periodu globalne finansijske krize (detaljnije Hasan \& Dridi, 2010). Konkretno, u Maleziji tokom perioda ekonomske krize započete 2008. godine, snaga uticaja makroekonomskih faktora na kreditni rizik u islamskim bankama je bila tako velika, da je uticaj internih faktora, poput strukture finansiranja, postao zanemarljiv (Rahman \& Shahimi, 2010, str. 94-95).

\section{Zaključak}

Kreditni rizik je glavni izvor poslovnih neuspeha islamskih banaka, ali ga, i pored toga, islamske banke smatraju manje bitnim od nekih drugih rizika. S obzirom na činjenicu da još uvek ne postoji set autentičnih, šerijatski usklađenih instrumenata upravljanja kreditnim rizikom, islamske banke uglavnom koriste konvencionalne hedžing instrumente. Upotreba ovih instrumenata $\mathrm{u}$ njihovom konvencionalnom obliku je, u većini slučajeva, nemoguća, pa ih stoga islamske banke pre implementacije moraju delimično modifikovati. Kod pojedinih instrumenata, poput kolaterala, garancije i limita u kreditiranju, osim poštovanja pojedinih ograničenja, značajnija modifikacija nije potrebna. To nije slučaj sa sekjuritizacijom i kreditnim derivatima, kod kojih modifikacije moraju biti takvog obima da samo efekat njihove primene ostaje isti, dok se svi ostali elementi ovih transakcija moraju, $\mathrm{u}$ većoj ili manjoj meri, modifikovati. Islamske banke mogu koristiti iskustva konvencionalnih banaka i kod procesa razmatranja i prihvatanja zahteva za finansiranjem. Ipak, islamske banke $\mathrm{u}$ ovom procesu često moraju biti daleko opreznije, naročito kod vlasničkih ulaganja, gde postoji izražen problem asimetrične informisanosti ugovornih strana i gde banke imaju slabe mogućnosti za kontrolu realizacije finansiranog projekta i adekvatnu zaštitu od rizika. Islamske banke, slično konvencionalnim bankama, formiraju i posebne rezerve za zaštitu svog poslovanja, pozicije akcionara $\mathrm{i}$, za njih karakteristično, investicionih deponenata, ali je način formiranja i upotreba ovih rezervi $u$ islamskom bankarstvu znatno drugačija u odnosu na konvencionalno bankarstvo.

Islamske banke karakteriše značajna kreditna izloženost pojedinim regionima, jer najveći deo poslovanja obavljaju u matičnim državama i regionima, i vrstama plasmana. Najveći deo svojih ulaganja, islamske banke usmeravaju u realni sektor, visoko su kapitalizovane i udeo neperformansnih ulaganja u ukupnim ulaganjima kod njih je mali. Zbog velikog učešća murabeha ulaganja u ukupnim ulaganjima i snažnog prisustva rizika promene marže kod ove vrste ulaganja, islamske banke percipiraju ovaj rizik opasnijim 
(the increase in the number of management and regulatory bodies, the number of their members, the share of independent members and the number of Shariah board members) and the low concentration of ownership (the share of the major shareholders in the ownership structure) mitigate the credit risk effect as they lead to a more transparent and accountable business (Bourakba \& Zerargui, 2015, p. 72). We should particularly emphasize the importance of Shariah boards, which can play a key role in disciplining Islamic banks. If they are independent, they have sufficient influence in the organization and a sufficient number of members with adequate expertise (Farook \& Lanis, 2007, p. 240-241).

Effective credit risk management is impossible without the existence of an adequate framework, which should define the instruments and regulations related to credit risk management. Over the past several decades, Islamic banks and international Islamic financial regulatory institutions have worked on developing such a framework, which could respond to the needs and demands of Islamic banks. However, the achieved results have been unsatisfactory, because a number of Shariah-compliant, authentic credit risk mitigation techniques available to Islamic banks is still small, which is why they are forced to use conventional techniques (Sundararajan \& Errico, 2002, p. 6; Nazir, Daniel \& Nawaz, 2012, p. 121). Therefore, one of the priority tasks of Islamic banks should be to intensify their engagement in the field of Islamic financial engineering and innovation, in order to mitigate the riskiness of the existing Islamic financial arrangements and develop new risk management techniques (Khan, 2006, p. 406407; Nazir, Daniel \& Nawaz, 2012, p. 121). This process is hindered by the still-present dilemma, whether to imitate conventional banks in credit risk management, despite it being clear that due to the vital differences between these two types of financial institutions, it is impossible to do so efficiently (Boumediene, 2010, p. 27).

Finally, we should not neglect the impact of macroeconomic factors on credit risk in Islamic banking (Waemustafa \& Sukri, 2015), although this is not a specificum of Islamic banking. The impact of these factors was particularly evident in the period of the global financial crisis (more detailed Hasan \& Dridi, 2010). In particular, in Malaysia, during the 2008 global economic crisis, the impact of macroeconomic factors on credit risk in Islamic banks was so huge that the impact of internal factors, such as the financing structure, became negligible (Rahman \& Shahimi, 2010, p. 94-95).

\section{Conclusion}

Credit risk is a major source of business failures of Islamic banks, but, despite this, Islamic banks consider it less important than some other risks. Considering the fact that there are still no authentic, Shariah-compliant credit risk management instruments, Islamic banks mainly resort to the conventional hedging instruments. The use of these instruments in their conventional form is, in most cases, impossible, and hence Islamic banks must partially modify them before implementation. For some instruments, such as collateral, guarantees and lending limits, apart from respecting certain constraints, no significant modification is required. This is not the case with securitization and credit derivatives, in which modifications must be of such extent that only the effect of their application remains the same, while all other elements of these transactions must, to a greater or lesser extent, be modified. Islamic banks can use the experience of conventional banks in the process of considering and accepting requests for funding. However, in this process, Islamic banks often have to be far more careful, especially with regard to equity investments, because there is a conspicuous problem of asymmetric information and banks have poor possibilities of controlling the implementation of the funded project and adequate risk protection. Islamic banks, similarly to conventional banks, set aside the special provisions for the protection of their business, the position of shareholders and, characteristically for them, investment depositors, but the ways in which these provisions are formed and used in Islamic banking significantly differ from conventional banking.

Islamic banks are characterized by a significant credit exposure to certain regions, since most of their operations are performed in their home countries and regions, and to 
po njihovo poslovanje od kreditnog rizika. $\mathrm{Na}$ intenzitet dejstva kreditnog rizika u islamskom bankarstvu utiču brojni faktori, od kojih su neki specifikum islamskih banaka. Kontrolom tih faktora, kreditni rizik u islamskim bankama se može ublažiti: dominantnim učešćem murabehe u strukturi plasmana, zbog niske rizičnosti ovog aranžmana, i investicionih depozita u strukturi izvora finansiranja, zbog mogućnosti banke da teret kreditnog rizika delimično prenese na investicione deponente; dostizanjem odgovarajuće veličine aktive banke, jer su male banke kapitalizovanije i manje sklone rizičnom poslovanju; visokim udelom religioznih klijenata u ukupnom broju klijenata, jer religioznost podstiče na poštovanje preuzetih obaveza; decentralizacijom upravljanja i niskom koncentracijom vlasništva, čime se onemogućava dominacija nekolicine aktera i stvaraju uslovi za transparentno i odgovorno poslovanje; razvojem šerijatski usklađenih hedžing instrumenata, čime bi se na adekvatan način odgovorilo na potrebe islamskih banaka. Na izloženost islamskih banaka kreditnom riziku, značajan uticaj imaju i makroekonomski faktori, čije je dejstvo bilo posebno intenzivno $\mathrm{u}$ periodu globalne ekonomske krize.

\section{Literatura / References}

1. Abedifar, P., Molyneux, P. \& Tarazi, A. (2013). Risk in Islamic banking. Review of Finance 17 (6), 2035-2096

2. Abu Dhabi Islamic Bank. (2017). Annual Report 2016. http://www.adib.ae/en/ SiteAssets/2017\%20PDFs/Annual\%20 Report\%202016\%20EN.pdf. 20.12.2017.

3. Abusharbeh, M. T. (2014). Credit risks and profitability of Islamic banks: Evidence from Indonesia. World Review of Business Research 4 (3), 136-147

4. Accounting and Auditing Organization for Islamic Financial Institutions. (1999). Statement on the Purpose and Calculation of the Capital Adequacy Ratio for Islamic Banks. Manama: Accounting and Auditing Organization for Islamic Financial Institutions

5. Ahmad, N. H. \& Ahmad, S. N. (2004). Key factors influencing credit risk of Islamic bank: a Malaysian case. The Journal of Muamalat and Islamic Finance Research 1 (1), 65-80
6. Ahmed, A. S., Takeda, C. \& Thomas, S. (1999). Bank loan loss provisions: a reexamination of capital management, earnings management and signaling effects. Journal of Accounting and Economics 28 (1), 1-25

7. Akkizidis, I. \& Khandelwal, S. K. (2008). Financial Risk Management for Islamic Banking and Finance. Palgrave Macmillan

8. Altman, E. (1968). Financial Ratios, Discriminant Analysis and the Prediction of Corporate Bankruptcy. The Journal of Finance 23 (4), 589-609

9. Al Rajhi Bank. (2017). Annual Report 2016. http://www.alrajhibank.com.sa/en/investorrelations/documents/annual_report_2016_ en.pdf. 20.12.2017.

10. Ayub, M. (2007). Understanding Islamic Finance. John Wiley and Sons Ltd. 
certain types of placements. The bulk of their investments Islamic banks direct to the real sector, they are highly capitalized and their share of non-performing investments in total investments is small. Due to the large share of murabahah investments in total investments and the strong presence of the mark-up risk in this type of investment, Islamic banks perceive this risk as being more dangerous for their operations than credit risk. The intensity of credit risk in Islamic banking is influenced by a number of factors, some of which are specific for Islamic banks. By controlling these factors, Islamic banks can mitigate credit risk by: the dominant share of murabahah in the structure of placements, due to the low riskiness of this arrangement, and investment deposits in the structure of the financing sources, due to the ability of the bank to partially transfer the credit risk burden to investment depositors; by reaching the appropriate size of bank assets, as small banks are more capitalized and less prone to risky operations; a high share of religious clients in the total number of clients, because religiousness encourages the honoring of one's commitments; decentralization of management and low concentration of ownership, which prevents the dominance of several players and generates the conditions for transparent and responsible business; the development of Shariah-compliant hedging instruments, which would adequately respond to the needs of Islamic banks. Macroeconomic factors also have a significant impact on the exposure of Islamic banks to credit risk, whose effect was especially intense during the global economic crisis.
11. Azmi, S., Nur, S., Hussin, N. \& Basiruddin, R. (2015). Examining the differences between Ar Rahnu and conventional pawn broking in compatibility towards maqasid shariah. U: Bahrom, H., Suyurno, S. S. \& Razak, A. Q. A. (Eds.). Islamic herigate leads the transformation of Ummah (455-466). 1st International Islamic Heritage Conference. Academy of Contemporary Islamic Studies, MARA University of Technology

12. Bahrain Islamic Bank. (2017). Annual Report 2016. https://bisb.com/media/document/ BisB_AR2016_English_v3.pdf. 20.12.2017.

13. Basel Committee on Banking Supervision. (1988). International Convergence of Capital Measurement and Capital Standards. Basel: Bank for International Settlement, http:// www.bis.org/publ/bcbs04a.pdf. 1.12.2017.

14. Basel Committee on Banking Supervision. (1991). Measuring and Controlling Large Credit Exposures. Basel: Bank for International Settlement. http:// www.bis.org/publ/bcbsc121.pdf. 1.12.2017.
15. Basel Committee on Banking Supervision. (2000). Principles for the Management of Credit Risk. Basel: Bank for International Settlement. https://www.bis.org/publ/ bcbs75.pdf. 1.12.2017.

16. Basel Committee on Banking Supervision. (2004). International Convergence of Capital Measurement and Capital Standards: a Revised Framework. Basel: Bank for International Settlement. https://www.bis.org/publ/ bcbs107.pdf. 1.12.1017.

17. Basel Committee on Banking Supervision. (2010). Basel III: A Global Regulatory Framework for More Resilient Banks and Banking Systems. Basel: Bank for International Settlement. http://www.bis.org/publ/bcbs189_dec2010. pdf. 1.12.1017.

18. Bebczuk, N. R. (2003). Asymmetric information in financial markets: introduction and applications. Cambridge, UK: Cambridge University Press

Nastavak na strani 50 / Continued on page 50 
Nastavak sa strane 49 / Continuation from page 49

19. Ben Khediri, K. \& Ben-Khedhiri, H. (2009). Determinants of Islamic bank profitability in the MENA region. International Journal of Monetary Economics and Finance 2 (3-4), 409-426

20. Bhatti, I. \& Misman, F. N. (2010). Risks Exposure in Islamic Banks: A Case Study of Bank Islam Malaysia Berhad (BIMB). Australian Centre for Financial Studies - Finsia Banking and Finance Conference 2010. https://ssrn. com/abstract=1632849. 22.12.2017.

21. Black, F. \& Scholes M. (1973). The Pricing of Options and Corporate Liabilities. Journal of Political Economy 81 (3), 637-654

22. Boulila Taktak, N., Ben Slama Zouari, S. \& Boudriga, A. (2010). Do Islamic banks use loan loss provisions to smooth their results? - Journal of Islamic Accounting and Business Research 1 (2), 114-127

23. Boumediene, A. (2010). Is Credit Risk Really Higher in Islamic Banks? https://ssrn.com/ abstract=1689885. 20.12.2017.

24. Bourakba, C. \& Zerargui, H. (2015). The relationship between credit risk and corporate governance in Islamic banking: An empirical study. Issues in Business Management and Economics 3 (4), 67-73

25. British Bankers' Association. (2006). Credit Derivatives Report 2006. London: British Bankers' Association.https://www.bba.org.uk/ publication/books-reports-and-subscriptions/ bba-credit-derivatives-report-2006. 5.12.2017.

26. Dionne, G. (2013). Risk management: History, definition, and critique. Risk Management and Insurance Review 16 (2), 147-166

27. Docking, D. S., Hirschey, M. \& Jones, E. (1997). Information and contagion effects of bank loan-loss reserve announcements. Journal of Financial Economics 43 (2), 219-239

28. Dubai Islamic Bank. (2017). Annual Report 2016. http://www.dib.ae/docs/investorrelation/financial-statments-2016-english. pdf. 20.12.2017.

29. El Gari, M. A. (2003). Credit Risk in Islamic Banking and Finance. Islamic Economic Studies 10 (2), 1-25

30. El-Gamal, M. (2006). Islamic finance: law, economics and practice. Cambridge University Press

31. Farook S. \& Lanis, R. (2007). Banking on Islam? Determinants of Corporate Social Responsibility Disclosure. U: Iqbal, M.,
Aly, S. S. \& Muljawan, D. (Eds.). Advances in Islamic Economics and Finance (217-247). Proceedings of 6th International Conference on Islamic Economics and Finance. Islamic Research and Training Institute, Islamic Development Bank

32. Fligstein, N. \& Goldstein, A. (2010). The anatomy of the mortgage securitization crisis. U: Lounsbury, M. \& Hirsch, P. M. (Eds.). Markets on Trial: The Economic Sociology of the US Financial Crisis (27-68). Emerald Group Publishing Limited

33. Hasan, M. \& Dridi, J. (2010). The Effects of the Global Crisis on Islamic and Conventional Banks: A Comparative Study. IMF Working Paper No. 10/201

34. Heffernan, S. (2005). Modern Banking. John Wiley and Sons Ltd.

35. Homer, S. \& Sylla, R. E. (2005). A history of interest rates. Fourth edition. Hoboken, New Jersey: John Wiley \& Sons, Inc.

36. How, J. C., Karim, M. A. \& Verhoeven, P. (2005). Islamic financing and bank risks: the case of Malaysia. Thunderbird International Business Review 47 (1), 75-94

37. Iqbal, Z. (2007). Challenges facing Islamic financial industry. Journal of Islamic Economics, Banking and Finance 3 (1), 1-14

38. Iqbal, Z. i Mirakhor, A. (2009). Uvod u islamske financije: Teorija i praksa. Zagreb: Mate

39. Islamic Financial Services Board. (2005a). Capital Adequacy Standard for Institutions (other than Insurance Institutions) offering only Islamic Financial Services. http://www.ifsb. org/standard/ifsb2.pdf. 3.12.2017.

40. Islamic Financial Services Board. (2005b). Guiding Principles of Risk Management for Institutions (other than Insurance Institutions) offering only Islamic Financial Services. http:// ifsb.org/standard/ifsb1.pdf. 3.12.2017.

41. Islamic Financial Services Board. (2016). Islamic Financial Services Industry Stability Report 2016. Kuala Lumpur, Malaysia: Islamic Financial Services Board. http:// www.ifsb.org/docs/IFSI Stability Report 2016 (final).pdf. 3.12.2017.

42. Islamic Development Bank Group \& World Bank Group. (2016). Islamic Finance - a Catalyst for Shared Prosperity, Global Report on Islamic Finance. https://openknowledge.worldbank. org/handle/10986/25738. 14.12.2017. 
43. Jobst, A. (2007). Derivatives in Islamic Finance. Jakarta, Indonesia: International Conference on Islamic Capital Markets

44. J. P. Morgan. (1997). Introduction to CreditMetrics. J. P. Morgan \& Co. Incorporated

45. Kane, E. J. (2009). Incentive Roots of the Securitzation Crisis and the Early Mismanagement. Yale Journal on Regulation 26 (2), 405-416

46. Khan, T. \& Ahmed, H. (2001). RiskManagement: An Analysis of Issues in Islamic Financial Industry. Jeddah: Islamic Research and Training Institute, Islamic Development Bank

47. Khan, T. (2006). Credit risk management: A framework for islamic banking. U: Khan, T. \& Muljawan, D. (Eds.), Islamic Financial Architecture: Risk Management and Financial Stability (399-407). Jeddah: Islamic Research and Training Institute, Islamic Development Bank

48. Khan, M. A. A., Muntaqua, G. \& Samad, M. A. (2008). Shari'ah's Drive Against Derivatives. U: Ali, S. (Ed.). Islamic capital markets: products, regulation and development (201-220). Islamic Research and Training Institute, Islamic Development Bank

49. Martin, J. D. (2010). A Primer on the Role of Securitization in the Credit Market Crisis of 2007. U: Kolb, R. W. (Ed.). Lessons from the financial crisis: Causes, consequences, and our economic future (197-207). John Wiley \& Sons

50. Merton, R. (1973). Theory of Rational Option Pricing. The Bell Journal of Economics and Management Science 4 (1), 141-183

51. Merton, R. (1974). On the Pricing of Corporate Debt: The Risk Structure of Interest Rates. The Journal of Finance 29 (2), 449-470

52. Nazir, M. S., Daniel, A. \& Nawaz, M. M. (2012). Risk management practices: A comparison of conventional and Islamic banks in Pakistan. American Journal of Scientific Research 68 (1), 114-122

53. Ng, J. \& Roychowdhury, S. (2014). Do loan loss reserves behave like capital? Evidence from recent bank failures. Review of Accounting Studies 19 (3), 1234-1279

54. Piskorski, T., Seru, A. \& Vig, V. (2010). Securitization and distressed loan renegotiation: Evidence from the subprime mortgage crisis. Journal of Financial Economics
97 (3), 369-397

55. Qatar Islamic Bank. (2017). Annual Report 2016. https: //www. qib. com. qa/en/images/ QIB-Financial-Statements-31-Dec-2016English1. pdf. 20. 12. 2017.

56. Rahman, A. A. \& Shahimi, S. (2010). Credit Risk and Financing Structure of Malaysian Islamic Banks. Journal of Economic Cooperation and Development 31 (3), 83-105

57. Sarker, A. (1999). Islamic Business Contracts, Agency Problem and the Theory of the Islamic Firm. International Journal of Islamic Financial Services 1 (2), 12-28

58. Shaikh, S. A. \& Jalbani, A. A. (2009). Risk management in Islamic and Conventional Banks: A Differential Analysis. Journal of Independent Studies and Research - MSSE 7 (2), 67-79

59. Stiglitz, J. \& Weiss, A. (1981). Credit rationing in markets with imperfect information. The American Economic Review 71 (3), 393-410

60. Sundararajan, V. \& Errico, L. (2002). Islamic financial institutions and products in the global financial system: Key issues in risk management and challenges ahead. Washinghton D. C.: International Monetary Fund

61. Usmani, M. T. (2003). Uvod u islamske finansije. Živinice: Selsebil

62. Van Greuning, H. i Brajović Bratanović, S. (2006). Analiza i upravljanje bankovnim rizicima. Zagreb: Mate

63. Van Greuning, H. \& Iqbal, Z. (2008). Risk Analysis for Islamic Banks. Washinghton D. C.: The International Bank for Reconstruction and Development, The World Bank

64. Visser, H. (2009). Islamic finance - principles and practice. Edward Elgar Publishing Limited

65. Waemustafa, W. \& Sukri, S. (2015). Bank specific and macroeconomics dynamic determinants of credit risk in Islamic banks and conventional banks. International Journal of Economics and Financial Issues 5 (2), 476-481

66. Wilson, R. (2007). Credit risk management in Islamic finance. https://fp.brecorder. com/2007/11/20071105648154. 20.12.2017. 